\title{
'One student might get one opportunity and then the next student won't get anything like that': Inequities in Australian career education and recommendations for a fairer future
}

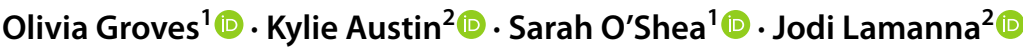

Received: 8 February 2021 / Accepted: 4 August 2021 / Published online: 19 September 2021

(c) The Australian Association for Research in Education, Inc. 2021

\begin{abstract}
Access to quality career advice is important for economic, personal and equity reasons, yet, in many countries around the world, career-education provision is of varying quality and quantity within school settings. Given the inconsistencies in careereducation resourcing and provision, what is not clearly understood is how students from low socioeconomic status (low SES) backgrounds experience career-education provision and the extent to which it shapes their post-school futures. Drawing on Australian research, this paper explores the career-education experiences of highschool students from low SES backgrounds. Bourdieu's tools of field, habitus and capital are used as a theoretical framework to understand how career education can influence students' imagining and achieving their career goals. The findings reported in this paper contribute nuanced understandings of career education to students from low SES backgrounds and recommends how all students can benefit from an embedded approach to career education in schools.
\end{abstract}

Keywords Career education - Career advice $\cdot$ Higher education - Equity in education · Low socioeconomic students

Olivia Groves

olivia.groves@curtin.edu.au

Kylie Austin

kaustin@uow.edu.au

Sarah O'Shea

sarah.oshea@curtin.edu.au

Jodi Lamanna

jlamanna@uow.edu.au

1 National Centre for Student Equity in Higher Education, Curtin University Australia, Bentley, Australia

2 University of Wollongong, Wollongong, Australia 


\section{Introduction}

Transitioning from school to work can be a challenging process for young people (Education Council, 2019; Foundation for Young Australians (FYA), 2018; OECD, 2016). In addition to complexities brought about by a new work reality, and developments in post-school education, the COVID-19 pandemic has further complicated this process. The short-and long-term career experiences, opportunities and trajectories of individuals continue to be directly impacted by COVID-19 (Akkermans et al., 2020). Young people have been disproportionally affected (Foundation for Young Australians, 2020) and those with lower levels of education even more so (Chinn et al., 2020). The "career shock" of the pandemic may have "significant career consequences for several years" and "long-term psychological effects" on young people (Akkermans et al., 2020, p. 3). Thus, COVID-19 has increased the challenge of moving from education into employment and exacerbated existing social inequalities (Chinn et al., 2020).

Internationally, it is recognised that countries need to work proactively to ensure that individuals reach their career goals, not only because of economic benefit but for personal and ethical reasons (Education Council, 2020; OECD, ILO, UNESCO, \& The European Commission, 2019). Quality career guidance or advice should be recognised as a basic human right (Career Development Association of Australia, 2012) as it shapes the society we live in and the wellbeing of individuals within it (Yates $\&$ Bruce, 2017). From a neo-liberal perspective, career advice "can help to make the best use of human resources in the labour market as well as in education by allowing better matches between skills and interests and opportunities for work and learning" (OECD, 2019, n.p.). Thus, career advice is important for workforce participation and national productivity (Australian Government, 2013). Ensuring that all citizens have access to quality career advice is also important for equity (Mann et al., 2020). This is because traditionally, shifts in skills demands have disproportionately affected workers with lower levels of skills and education, and the rewards of the new work reality are unlikely to be bestowed evenly among the workforce (Torii, 2018). Quality career advice becomes a "social compensatory measure" which enables people "to participate effectively in society" (International Centre for Career Development and Public Policy (ICCDPP), 2019, n.p.). However, what is not well understood is to what extent the current career provision addresses societal inequities in education and employment.

The aim of this paper is to explore how career advice is experienced by students from low SES backgrounds and how current approaches to the provision of careers can shape educational and employment outcomes for this cohort. This paper begins by introducing what is meant by career education.

\section{Current approaches to career education}

There are a wide range of terms and definitions which determine the scope and nature of career-education provision in schools. For clarity, this paper uses the term 'career education' to refer to "development of knowledge, skills and attitudes through a planned program of learning experiences in education and 
training settings to assist students to make informed decisions about their study and work options to enable effective participation in working life" (Australian Government, 2019, p. 3).

The current and most prevalent approach to the provision of career education in schools is through the appointment of a career adviser or career counsellor. The function of the school career adviser is to assist young people in conceptualising their interests and skills whilst also providing information about career pathways and options (NSW Government, 2019). It is also expected that career advisers develop career programmes, organise work-experience placements and host career-related events (Aspden et al., 2015; Brown et al., 2019; Gore et al., 2015). Studies such as Christie's (2016) highlight how career advisers often have a strong sense of responsibility for their students and seek to positively influence their post-school education and employment opportunities.

Whilst the role of career advisers is acknowledged in terms of the significant impact these individuals can make on students' choice of school subjects and careers (Aspden et al., 2015; Whiston et al., 2017), there are structural and institutional issues associated with the provision of career education in countries such as Australia, New Zealand, the United Kingdom and the United States (Brown, 2015; Moote \& Archer, 2018; Parliament of Victoria, 2018; Yates \& Bruce, 2017). The recent Australian review of senior secondary pathways into work, further education and training states that "career advice nationally is inadequate" (Education Council, 2020 , p. 18). Specifically, concerns have been raised about career education's quality, equitable provision and policy.

First, traditional career advice focusses on supporting students' transition out of school into work or further study, but career education needs to do more than this; it needs to equip students with the skills to navigate the world of work over their lifetime (Parliament of Victoria, 2018). As a result, stakeholders suggest that current career provision does not meet the needs of students (Parliament of Victoria, 2018). Students also suggest that they are not getting their needs met, wishing that they had received more information about all of the options available to them (Skillsroad, 2018).

Second, the quantity of career education varies significantly between schools, with not all schools having equal careers provision. One Victorian study found that $10 \%$ of schools spent 45 min or less on career education per student per year and $10 \%$ spent $12 \mathrm{~h}$ or more per student per year (Parliament of Victoria, 2018). Arguably, such differences would likely have a profound impact on students' career aspirations and knowledge, and therefore, outcomes. This pattern is echoed internationally too, with a recent large-scale OECD analysis finding that young people from 'disadvantaged' backgrounds had less access to career development activities (Mann et al., 2020). The reason for such variations in quantity of delivery can be a result of the availability of resources which is frequently cited as a problem for the provision of career education in schools in Australia as well as those in England (Career Development Association of Australia, 2012; Career Industry Council of Australia (CICA), 2015; Hooley \& Dodd, 2015; Moote \& Archer, 2018; Youth Action, 2017). In some schools, the central resource in the traditional provision of career education, the career adviser, is often a part-time staff member with additional classroom 
teaching responsibilities (CICA, 2017a). This is a situation which contributes to low quantities of career-education provision in those schools.

Third, the policy framework for career education in Australian schools is fragmented and ineffectual (Australian Government, 2019; Parliament of Victoria, 2018; Patton, 2019) with neither the Australian Blueprint for Career Development (Ministerial Council on Education, 2010), nor professional standards and benchmarking resources (CICA, 2014) being compulsory. Patton (2019) observes that careers strategies and policies are politically driven-researched, developed and implemented in response to political agendas in "repeating cycle of decades of reports, ineffective policy action and even more ineffective practice implementation" (Patton, 2019, p. 264). Andrews and Hooley (2017) suggest that a lack of nationally agreed standards and regulation of career work in the United Kingdom may result in unequal outcomes for young people (Andrews \& Hooley, 2017).

Within this imperfect context of career education, it is not surprising that career advisers are not sufficiently supported to do their work and that not all students are achieving equitable outcomes from their schooling and careers. The following section examines the outcomes of one group of students, those from low SES backgrounds, and what we know about how they aspire to and make decisions about their educational and vocational futures.

\section{Career aspiration and decision making of students from low SES backgrounds}

In Australia, there are $\operatorname{six}^{1}$ groups of students that are recognised as having inequitable academic and employment outcomes in comparison to the broader population (Department of Education, 2018), one of these being students from low SES backgrounds. As a result of structural and societal barriers, students from low SES backgrounds can experience lower achievement levels, non-completion of schooling (Education Council, 2019; McLachlan et al., 2013), and are under-represented in further and higher education (Brett, 2018; Cunninghame, 2017; Li \& Carroll, 2017; Ranasinghe et al., 2019). Furthermore, rates of participation in the workforce, overall employment, and full-time employment for people from economically disadvantaged backgrounds are significantly lower than the rest of the population (Cunningham et al., 2014; Lamb et al., 2015).

Arguably the causes of inequitable academic and employment outcomes for students from low SES backgrounds are complex; however, large-scale research by the OECD found that educational and vocational aspirations and decision making are linked to the social inequities experienced by individuals from diverse socioeconomic backgrounds, as well as other factors such as gender and familial background

\footnotetext{
1 Australia has six identified equity groups which include students with a disability; regional, rural and remote (RRR) students; Aboriginal and Torres Strait Islander (ATSI) students; students from low socioeconomic (low SES) backgrounds; students from non-English speaking backgrounds (NESB); and women in non-traditional areas (WINTA).
} 
(Mann et al., 2020). The following discussion explores how the aspirations and decision-making processes of students from low SES backgrounds are influenced by social and cultural inequalities.

There are distinctions in the ways in which people from different socioeconomic backgrounds access information regarding education and career decision making (Archer et al., 2014; Smith, 2011). There is evidence that young people from low SES backgrounds are more likely to rely on informal, 'word-of-mouth' knowledge about careers from social sources such as family, friends and teachers (Ball \& Vincent, 1998; Greenbank, 2011; Smith, 2011; Vernon \& Drane, 2021) than from formal sources produced by governments, institutions and schools; and communicated via websites, enrolment information, and statistical data (Smith, 2011). Given that students from low SES backgrounds may not have ready access to informed sources or to those who have direct experience, it is perhaps unsurprising that decisions about futures are made with limited or incorrect information resulting in more difficult transitions (Mann et al., 2020).

As a result of embedded social inequities, students from low SES backgrounds also draw upon social, economic and cultural capitals in diverse ways, when aspiring and making decisions about their future careers (Greenbank, 2009). For example, in order to enact one's aspiration, an individual needs to draw upon knowledge, skills, networks and resources to successfully manoeuvre between complex educational institutions and vocational structures (Smith, 2011). Navigating this process requires a specific understanding of the ways in which large institutions and pathways into and through education and work operate. Often, students from low SES backgrounds have not experienced or been exposed to these understandings in order to successfully direct themselves through this journey (Irving, 2009).

Formation of aspirations are also shaped by socioeconomic background. Although research has shown that students from low SES backgrounds have similar career aspirations to those from higher SES backgrounds (Gore et al., 2017), Smith (2011, p. 166) argues that those aspirations can be more 'brittle' as a result of having fewer concrete experiences, opportunities and resources to draw on when navigating pathways. What students from low SES backgrounds perceive to be both desirable and realistically achievable, may be a result of their limited access to social, cultural and economic resources (Smith, 2011) as well as prior achievement, gender and year level (Gore et al., 2017). Aspirations and educational decision making are also a product of students' own 'risk-tolerance' (Raciti, 2019, p. 13). For example, secondary students from low SES backgrounds respond differently to the dilemma of deciding whether or not to go to university, being more likely to be risk averse, and slower and more careful in their decision-making process (Raciti, 2019). In these ways, education and employment outcomes for students from low SES backgrounds are shaped by their and their families' experiences, as well as the resources available to them.

As the research and literature demonstrates, career education is important for educational and career outcomes, but in some schools the provision of this type of support is inconsistently resourced and implemented. At the same time, students from low SES backgrounds aspire, access career-related knowledge, and make decisions in different ways from their peers. What remains unclear however, is exactly 
how SES background interacts with current careers provision in shaping the educational and employment outcomes for this cohort. This paper aims to show how some career-education practices continue to disadvantage some groups of students and makes specific recommendations as to how strong education and career outcomes for students from low SES backgrounds can be best achieved. The following section provides an overview of how Bourdieu's methodological tools were used in the study and are applied in this paper to explore the problem.

\section{Theoretical framework}

Bourdieu's (1986) perspectives on social reproduction and the tools of field, habitus and capital were used in this study as a theoretical framework to understand the structures within society that can shape how students imagine and achieve their career goals. Specifically, Bourdieu's tools of 'field', 'habitus' and 'capital' were used as a lens to provide a richer understanding of how career education can operate to open up and support individuals' educational and career aspirations. This theoretical framing was also used to explore the social context in which career education exists by identifying the structural barriers that prevent students from fully realising their career goals.

'Field' describes the setting in which agents and their social positions are located (Bourdieu, 1979). 'Field' was used to explore deeply how the different contexts that family, educational providers, industry bodies, and students themselves occupy, influence their understanding of how career education is provided. The blurring of fields (Kaiserfeld, 2013; Powell \& Solga, 2010) or bridges between fields (Colley et al., 2014), such as the intersection between school and family, allowed for the construction of new rules, dispositions and languages in relation to career education and identified new ways of working to emerge in the provision of career education.

'Habitus' relates to the set of culturally learned dispositions, skills and ways of knowing that explain how social and cultural messages shape an individual's thoughts and actions, and how that individual will operate in the field or in society (Bourdieu, 1979). This study drew on a diverse group of stakeholders, including students, parents, staff in schools, other education providers, industry and community groups, who each brought varied values, dispositions and practices to the conversations around effective career education. This provided rich and unique data sets that could be explored in the analysis phase of this study in shaping how career education should evolve to enable these stakeholder groups to meet the needs of students from low SES backgrounds.

A person's economic, cultural and social 'capital' is linked to their habitus and their field. 'Cultural capital' is the accumulation of knowledge, skills and behaviours through socialisation and education (Bourdieu, 1979). 'Social capital' refers to the networks, knowledge and resources to which individuals have access. These networks significantly contribute to the bank of knowledge that individuals acquire around communication, culture and power in society (Bourdieu \& Passeron, 1990). In this paper, the concepts of social and cultural capital are considered in exploring how knowledge, resources and networks are transmitted to students through 
effective career-education provision to inhibit or support student's imagining and achievement of their long-term career goals.

\section{Methodology}

The research reported on in this paper is part of a larger project which explored bestpractice career advice for students from low SES backgrounds funded by the Department of Education, Skills and Employment (DESE), and managed by the National Centre for Student Equity in Higher Education (NCSEHE). Approval to undertake the research was received from the appropriate university Human Research Ethics Committees (HREC). A mixed-methods approach was implemented across four collaborative and iterative stages of the project. This paper reports on the qualitative data collection which sought to understand how young people from low SES backgrounds make decisions about their educational and vocational futures.

\section{Participants}

This article draws on data collection with three groups of participants: current university students from low SES backgrounds $(n=72)$, parents of students from low SES backgrounds $(n=41)$, and key stakeholders $(n=16)$. University students were recruited via an email targeted at those who had participated in widening participation activities. Parents were invited to participate via advertisements in university newsletters and on social media platforms. Key stakeholders were recruited via email invitation from investigator/practitioner contact lists and included career advisers, school leaders, equity practitioners, career-service providers and members of industry bodies.

Bringing together the perspectives of three groups of participants was a purposeful component of the research design, as informed by the theoretical framework, intended to challenge the concepts of traditional models of career education, based on participants' own dispositions, values and experiences. Indeed, this recruitment strategy brought to the project students and parents from diverse backgrounds. Table 1 provides an overview of the equity markers with which participants selfidentified which speaks to the diversity of participants in this study.

Qualitative research acknowledges the researchers as participants in it. This is particularly the case for interviews/focus groups in which meaning is socially coconstructed by interviewees and interviewers (Berger, 2015). The four (female) authors of this paper comprise the research team: the first a post-doctoral researcher in educational equity; the second a higher-education equity manager and $\mathrm{PhD}$ student; the third a professor of equity in higher education; and the fourth, a PhD student in education. In combination, the researchers brought to the project experience in school teaching, equity and outreach work, research skills, as well as their own experiences as students from identified equity groups. 
Table 1 Parent and student demographics

\begin{tabular}{llllllll}
\hline Participant type & Low SES & FiF & RRR & Disability & ATSI & Refugee & NESB \\
\hline University students & 21 & 30 & 44 & 8 & 5 & 3 & 10 \\
Parents & 12 & n/a & 4 & 3 & 2 & 0 & 3 \\
\hline
\end{tabular}

More female students $(n=55)$ were recruited to the project than male $(n=17)$. Student participants ranged in age from 17 to 50 years of age

low SES student from low socioeconomic status background, FiF first in family to attend university, RRR from a regional, rural or remote location, disability student with disability, ATSI Aboriginal or Torres Strait Islander background, Refugee from a refugee background, NESB Non-English-speaking background

\section{Data collection}

Student and parent participants were offered the choice between participating in a focus group/interview ( $n=27$ and 3 respectively) or completing an online survey ( $n=45$ and 38 respectively). Student focus groups ( $n=7$ groups) were conducted face-to-face, and student and parent interviews via phone ( $n=4$ and 3 respectively). Stakeholders $(n=16)$ were interviewed via telephone. Authors one, two and four conducted all interviews and focus groups.

The overarching purpose of questions asked of participants was similar across each mode of engagement but did vary according to participant type. Students and parents were asked to describe their (child's) educational and career journey; the career advice that they (their child) had received whilst at school; key decision points; and conversations or experiences which had been influential on their (child's) journey. Stakeholders were also asked to comment on the quality of career advice given in schools; key decision points for students; key influencers of students' educational and career journeys; as well as how their organisation delivers career advice or supports school students' career-education activities.

\section{Data analysis}

The analysis of the data was informed by social constructivist grounded theory. Social constructivist grounded theory "assumes the relativism of multiple social realities, recognises the mutual creation of knowledge by the viewer and the viewed, and aims toward interpretative understanding of subjects' meanings" (Charmaz, 2000 , p. 510). The use of social constructivist grounded theory embraced an emergent design, as it allowed for both the researchers and the participants to create new meaning and understandings of career education for students from low SES backgrounds through the data analysis (Charmaz, 2000).

The transcripts were uploaded into the NVivo software and analysed using axial coding - specifically, a two phased inductive and deductive data analysis approach (Glaser \& Strauss, 1967). Firstly, inductive open coding was undertaken by three of the researchers. Then the emerging codes were reviewed and interrogated by all four 
members of the research team, each writing up reflective commentary based on the initial coding. The initial themes and notes were discussed as a team and the combined insights from all team members formed an exploratory framework. Deductive coding then followed, whereby the data were re-coded utilising the exploratory framework. This resulted in a set of five themes, each deeply embedded in the data but conceptually dense. This paper delves deeper into one of those themes to provide further insight into the current provision of career education for students from low SES backgrounds and its impact on equity and student outcomes of education.

The following analysis and discussion are guided by the research question: How does socioeconomic status and current career-education provision interact to shape educational and employment outcomes?

\section{Findings}

Currently, career provision in schools is centred on the work of a career adviser who implements career-focussed activities such as individual consultations and work experience. The research revealed both benefits and challenges for this model of career education. The key issues found will be explored under the headings:

- "She simply did not click with me": Career adviser support and connecting with students

- "They just don't have the time": Career adviser time and resourcing of career education

\section{"She simply did not click with me": career adviser support and connecting with students}

In this study, the need for individual career support was emphasised by both stakeholders and students. Nicola (career adviser, rural low SES high school) explained having "one-on-one interviews where I can narrow down exactly what they're thinking of" allowed her to "source more information that's relevant to what they want to do rather than set them off on one of the websites to explore". Equally, Cheryl (career adviser, outer regional low SES high school) highlighted that individual interviews were the most appropriate environment to provide effective guidance, as "they feel special because it's a one-on-one thing-I take the time to spend a whole period with them on their own and there's no interference from other people".

Data from the students revealed that the personal qualities of the career adviser were key to these interactions. Students spoke positively of advisers who were available, helpful and accommodating, and reflected negatively on those who were not perceived in this way. "The school did have a career counsellor however, I remember them being very unhelpful and regularly unavailable" (student, F, 21-25 years, B. Law, \#31). Sustaining a personal connection seemed key in student-adviser relationships, and this characteristic influenced the extent that students would seek help. Two students reflected on needing an adviser whom they 'clicked with'; that is, 
someone who was personable and worked to develop a connection with students. "I was unlikely to ask the careers officer at school, as I did not think much of her. This doesn't mean she was not good, but she simply did not click with me" (student, M, 18-20 years, B. Science/B. Engineering, \#1). Other students referred to how their relationship with their career adviser influenced their engagement with the career provision at their school. One student stated that, "due to the distanced relationship [the career adviser] maintained with my cohort throughout year 12, [it made] me feel as if they didn't have any idea as to how to guide students to make informed decisions" (student, F, 18-20 years B. Applied Science, \#39). In contrast, Jennifer, university student equity project officer, has seen the difference a career adviser who had developed close relationships with students can make:

it wasn't just about handing out those manuals and doing those structured, really dry sessions, but it was more about learning what motivates the student as an individual and kind of walking alongside them in that journey. (Jennifer, university student equity project officer)

Clearly, rapport building and getting to know students is an important quality of a career adviser that was valued by students who participated in this study. Resourcing and strategies that provide the time to allow career advisers to build rapport and accessibility to the students within their school is an important consideration for future career provision.

\section{"They just don't have the time": career adviser time and resourcing of career education}

An issue for career education in schools, particularly schools with high proportions of equity students enrolled, is insufficient resourcing, resulting in inconsistent provision across schools. Stakeholders in career education highlighted time as a fundamental resource in providing career education, but time constraints meant that some areas of provision or groups of students missed out. In schools where a career adviser is not allocated enough time, students are denied much-needed contact or engagement with a career adviser. Lucy, CEO of a work-placement provider, described the situation of career advisers in small rural schools, where they might only be allocated two periods a week to undertake their work:

They... don't get to spend any time at all with the students.... They get exactly the same mail, exactly the same emails as a full-time career adviser in a high school, they've got the same sorts of jobs to do, albeit with a smaller cohort, but they still have all of the career adviser roles to take on. But they just don't have the time to devote to it. (Lucy, work-placement provider CEO)

A lack of time might mean that a career adviser must make limiting decisions. One such constraint, as Lucy (work-placement provider CEO) identified, might be not having individual consultations with students, or delivering career-focussed lessons. William, a career adviser in a large regional high school of over 1200 students highlighted the challenges that the limited resources 
presented for him as he only has time to work with students initially to 'generate ideas', leaving them to continue their journeys independently. Another implication might be the need to focus primarily on senior students, with younger students receiving no, or limited, career education.

Similarly, the availability of work-experience opportunities is affected by resourcing of the career adviser position, requiring careers advisers to make challenging decisions about the priorities of the career provision in their school. The time-consuming nature of organising work placements means that students in some schools have limited or no access to them. Stakeholders reported that some schools are offering work experience on a "needs basis" (Cheryl, career adviser, outer regional low SES high school), and that "if kids want to do it, they have to go and find their own work experience" (Tia, Chamber of Commerce and industry HR business partner), a challenging task for many young people but particularly those students who do not have access to the social and economic capitals necessary to do so. A few students expressed regret at the unavailability of work experience. This situation exists despite "stacks of employers being 'happy to host students for work placement'", according to Lucy, (workplacement provider CEO). She added, "it's just become a bit too hard for career advisers to organise anymore; it's very time-consuming".

Another result of having to prioritise aspects of the career provision in schools was that student cohorts were targeted for career education. For example, some schools focussed on "university entry, preparing students for university", which meant that students not following this pathway were "left out" (Lucy, workplacement provider CEO). In another school, information was provided to some students and not others. Justine (20, B. Science, Medical Biotech) reported that she was not provided with information about potentially highly valuable university access programmes: "a lot of the programs...they would provide that information to the top-graded students; I don't remember doing a [University Outreach Program], never given the opportunity to do summer [University Access Program], or stuff like that" (Justine, 20, B. Science, Medical Biotech).

Whilst grants and funding for low SES schools can be obtained, they are not always available and take considerable time and skill to apply for. When they are not available, schools cannot provide access to a wide variety of career-education activities. Arielle (university outreach officer) described the ad-hoc nature of career interventions that result from provision that depends on opportunity rather than strategy.

Often what will happen is [that] as government funding will come in and out and one year there'll be a huge science fair... and then you'll get a few students who are lucky enough to be in the right year groups or whatever for that year. (Arielle, university outreach officer)

Arguably, career education is inequitably available and prioritised across schools with some students from low SES backgrounds experiencing limited provision because of constraints on careers resourcing and time. 


\section{Discussion and conclusion}

In many schools, according to the current model of career provision, career advisers are often the sole provider of career education to students (Education Council, 2020; NSW Government, 2019). Although career advisers can be highly effective and valuable (Aspden et al., 2015; Career Industry Council of Australia (CICA), 2017; Christie, 2016), some students in this study did not avail of individual consultations because a personal connection had not been formed. At the same time, stakeholders reported that insufficient resourcing of careers meant that some areas of provision or some groups of students missed out on career-education experiences such as individual consultations and work experience.

The implications of these weaknesses in the current system of career education are more profound for low SES students than for their counterparts. This is due to the differences in the ways students from low SES backgrounds access information and make decisions about their careers, and their access to the capitals required to self-navigate the school to work transition. Successful navigation of post-school pathways requires specific capitals which students from low SES backgrounds might not have access to (Bok, 2010; Cuervo et al., 2019). Social capital might include personal contacts and networks of people who know about preferred pathways and careers (Cuervo et al., 2019; Smith, 2011). Economic capital might include access to reliable transport and time off work to attend external information days. Cultural capital might include knowledge about careers; skill in accessing and interpreting career information; job searching and application ability; and personal experiences of different jobs, institutions, and geographic locations. Quality career education has the potential to enable access to cultural, economic and social capital required for educational and career success (Chesters \& Smith, 2015; Patton, 2019). For example, career education which includes work experience, industry visits, open days, career expos, networking, and mentoring builds the cultural and social capital of students and enables students from low SES backgrounds to access such opportunities (Chesters \& Smith, 2015; Cuervo et al., 2019; Smith, 2011). It can contribute to increased education and employment outcomes for students from low SES backgrounds (Australian Government, 2013; Bajada \& Trayler, 2014; Chesters \& Smith, 2015). However, when limitations in career education are combined with aspects of students' backgrounds, disadvantage is promoted, rather than alleviated.

The findings reported in this paper highlight the need for adequate resourcing to be provided to career advisers to build personal relationships with students. Given that students from low SES backgrounds tend to access career-related information from informal, social sources rather than formal ones (Greenbank, 2011; Smith, 2011), a career adviser who has the time to build personal relationships is a powerful bridge. Specifically, a career adviser can mediate between the student and formal knowledge, providing the student with accurate information in a form which they trust and can readily take up. A career adviser can mitigate disadvantage caused by limited- and mis-information which can be problematic with socially received knowledge (Greenbank, 2009; Smith, 2011). Thus, 
relationship-building with students, the largely 'invisible' work of career advisers, needs to be made explicit and recognised for the time commitment it requires.

Stemming from this research, it is recommended to expand career provision beyond the responsibility of the career adviser to improve educational and employment outcomes for students from low SES backgrounds. A model which takes a whole-school approach to career education values the expertise of the career adviser but spreads obligations for career support amongst all members of the school, particularly classroom and subject specialist teachers (Parliament of Victoria, 2018; Yates \& Bruce, 2017). Within this model, all teachers embed career knowledge and linkages in their lessons and curriculum and are available to students for career conversations (Furbish \& Reid, 2013; Yates \& Bruce, 2017). In this way, students can build on existing relationships that they have already developed with their classroom teachers to further develop their understanding of the post-school education and employment pathways available to them. A whole-school approach which increases a student's network expands the social connections and social capital of the student allows them to access the knowledges, experiences and cultural capital of the broader school staff, and promotes educational aspiration and attainment (Chesters \& Smith, 2015; Vernon \& Drane, 2021).

A second recommendation which might assist in overcoming limited career provision caused by inadequate resourcing is to develop collaborative multi-stakeholder partnerships. The inclusion of multiple stakeholders such as universities, vocational-education providers, industry and community, in career education provides overburdened schools and career advisers with additional expertise, time and resources (Torii, 2018). Multi-stakeholder, whole-of-community partnerships provide increased opportunities for students to explore a range of career options and pathways (Torii, 2018) thereby expanding the capitals of students involved. Further, such approaches to career partnerships allow career education to be tailored to the needs of the local region and reflect the differing needs and goals of diverse learners (Education Council, 2019; Torii, 2018). Established according to best practice (Austin et al., 2020), multi-stakeholder partnerships have the potential to alleviate inequities and support the consistent, quality provision of career education (Office for Students, 2019; Torii, 2018).

This article has drawn on the experiences of students who either initially or eventually pursued a university education. Further research which explores the careereducation experiences of those who pursued other educational or vocational pathways would enrich our knowledge of the provision of career education and is an area for further research.

Author contributions All authors contributed to the study conception and design. Material preparation, data collection and analysis were performed by all authors. The first draft of the manuscript was written by Olivia Groves and all authors commented on previous versions of the manuscript. All authors read and approved the final manuscript.

Funding This work was supported by the National Centre for Student Equity in Higher Education (NCSEHE) under the 2019 Research Grants program. 


\section{Declarations}

Conflict of interest The authors report no conflict of interest.

Consent to participate All participants consented to participate in the study. This consent was informed and implied by the completion and submission of a survey, or obtained in writing or verbally for interview/ focus group participants.

Consent for publication All participants consented to their data being used for publication purposes. This consent was informed and implied by the completion and submission of a survey, or obtained in writing or verbally for interview/focus group participants.

Ethical approval Approval to conduct the research was received by the University of Wollongong Human Research Ethics Committee (HREC2019/345).

\section{References}

Akkermans, J., Richardson, J., \& Kraimer, M. (2020). The Covid-19 crisis as a career shock: Implications for careers and vocational behavior. Journal of Vocational Behavior, 119, 103434.

Andrews, D., \& Hooley, T. (2017). ' ... and now it's over to you': Recognising and supporting the role of careers leaders in schools in England. British Journal of Guidance and Counselling, 45(2), 153164. https://doi.org/10.1080/03069885.2016.1254726

Archer, L., DeWitt, J., \& Wong, B. (2014). Spheres of influence: What shapes young people's aspirations at age 12/13 and what are the implications for education policy? Journal of Education Policy, 29(1), 58-85. https://doi.org/10.1080/02680939.2013.790079

Aspden, T., Cooper, R., Liu, Y., Marowa, M., Rubio, C., Waterhouse, E.-J., \& Sheridan, J. (2015). What secondary school career advisors in New Zealand know about pharmacy and how that knowledge affects student career choices. American Journal of Pharmaceutical Education, 79(1), 7-14. https:// doi.org/10.5688/ajpe79107

Austin, K., O’Shea, S., Groves, O., \& Lamanna, J. (2020). Guide to partnerships. Retrieved from https:// documents.uow.edu.au/content/groups/public/@web/@dvce/@in2uni/documents/doc/uow264919. pdf. Accessed 18-22 Jan 2021

Australian Government. (2013). National career development strategy. Retrieved from https://docs.educa tion.gov.au/system/files/doc/other/national_career_development_strategy.pdf. Accessed 18-22 Jan 2021

Australian Government. (2019). A student focused national career education strategy. Retrieved from https://docs.education.gov.au/system/files/doc/other/future_ready_a_student_focused_national_ career_education_strategy.pdf. Accessed 18-22 Jan 2021

Bajada, C., \& Trayler, R. (2014). A fresh approach to Indigenous business education. Education \& Training, 56(7), 613-634. https://doi.org/10.1108/ET-07-2014-0079

Ball, S., \& Vincent, C. (1998). 'I heard it on the grapevine': 'Hot' knowledge and school choice. British Journal of Sociology of Education, 19(3), 377-400. https://doi.org/10.1080/0142569980190307

Berger, R. (2015). Now I see it, now I don't: Researcher's position and reflexivity in qualitative research. Qualitative Research, 15(2), 219-234. https://doi.org/10.1177/1468794112468475

Bok, J. (2010). The capacity to aspire to higher education: 'It's like making them do a play without a script.' Critical Studies in Education, 51(2), 163-178. https://doi.org/10.1080/17508481003731042

Bourdieu, P. (1979). Distinction: A social critique of the judgement of taste. Harvard University Press.

Bourdieu, P. (1986). The forms of capital. In J. Richardson (Ed.), Handbook of theory and research for the sociology of education (pp. 241-257). Greenwood Press.

Bourdieu, P., \& Passeron, J. (1990). Theory, culture \& society. Reproduction in education, society and culture (2nd ed.,) (R. Nice, Trans.). Sage Publications.

Brett, M. (2018). Equity performance and accountability. Retrieved from https://www.ncsehe.edu.au/ wp-content/uploads/2018/07/MattBrett_FellowshipReport_FINAL_ACCESSIBLE.pdf. Accessed 18-22 Jan 2021 
Brown, S. (2015). Exploring the district-wide school counselor leader's role in creating a college readiness culture. Fordham University.

Brown, J., Healy, M., McCredie, T., \& McIlveen, P. (2019). Career services in Australian higher education: Aligning the training of practitioners to contemporary practice. Journal of Higher Education Policy and Management, 41(5), 518-533.

Career Development Association of Australia. (2012). Report on the 6th International Symposium on Career Development and Public Policy. Retrieved from https://docs.education.gov.au/system/files/ doc/other/report_on_the_6th_international_symposium_on_career_development_and_public_policy.pdf. Accessed 18-22 Jan 2021

Career Industry Council of Australia (CICA). (2015). Lack of funding deprives young Australians of necessary career support [Press release]. Retrieved from https:/cica.org.au/wp-content/uploads/Lackof-Funding-Deprives-Career-Support-_-CICA-McCrindle-MR.pdf. Accessed 18-22 Jan 2021

Career Industry Council of Australia (CICA). (2017). The role of career practitioners in our schools. Retrieved from https:/cica.org.au/wp-content/uploads/CICA-Infographic-The-Role-of-Career-Pract itioners-in-Our-Schools.pdf. Accessed 18-22 Jan 2021

Charmaz, K. (2000). Grounded theory: Objectivist and constructivist methods. In N. Denzin, \& Y. Lincoln (Eds.), Handbook of qualitative research (pp. 509-535). Thousand Oaks: Sage.

Chesters, J., \& Smith, J. (2015). Social capital and aspirations for educational attainment: A crossnational comparison of Australia and Germany. Journal of Youth Studies, 18(7), 932-949.

Chinn, D., Klier, J., Stern, S., \& Tesfu, S. (2020). Safeguarding Europe's livelihoods: Mitigating the employment inpact of COVID019. Retrieved from https://www.mckinsey.com/industries/public-andsocial-sector/our-insights/safeguarding-europes-livelihoods-mitigating-the-employment-impact-ofcovid-19. Accessed 18-22 Jan 2021

Christie, F. (2016). Careers guidance and social mobility in UK higher education: Practitioner perspectives. British Journal of Guidance and Counselling, 44(1), 72-85. https://doi.org/10.1080/03069 885.2015 .1017551

CICA. (2014). School career development service benchmarking resource. Retrieved from https://cica. org.au/wp-content/uploads/CICA-School-Career-Benchmarking-Resource1.pdf. Accessed 18-22 Jan 2021

CICA. (2017a). Equipping the next generation in an increasingly complex environment. Retrieved from https://cica.org.au/wp-content/uploads/CICA-Media-Release-3-May-2017.pdf. Accessed 18-22 Jan 2021

Colley, H., Chadderton, C., \& Nixon, L. (2014). Collaboration and contestation in further and higher education partnerships in England. A Bourdieusian field analysis. Critical Studies in Education, 55(2), 104-121.

Cuervo, H., Chesters, J., \& Aberdeen, L. (2019). Post-school aspirations in regional Australia: An examination of the role of cultural and social capital. The Australian Educational Researcher, 46, 843861. https://doi.org/10.1007/s13384-019-00305-7

Cunninghame, I. (2017). The role of higher education in facilitating social mobility. International Studies in Widening Participation, 4(1), 74-85.

Cunningham, M., Orsmond, D., \& Price, F. (2014). Employment outcomes of the economically disadvantaged. Retrieved from https://www.rba.gov.au/publications/bulletin/2014/mar/pdf/bu-0314-3.pdf. Accessed 18-22 Jan 2021

Department of Education. (2018). 2017 Section 11-Equity groups. Retrieved from https://docs.educa tion.gov.au/documents/2017-section-11-equity-groups. Accessed 18-22 Jan 2021

Education Council. (2019). The review of senior secondary pathways into work, further education and training. Background paper. Retrieved from https://www.pathwaysreview.edu.au

Education Council. (2020). Looking to the Future. Report of the review of senior secondary pathways into work, further education and training. Retrieved from https://uploadstorage.blob.core.windows. net/public-assets/education-au/pathways/Final\%20report\%20-\%2018\%20June.pdf. Accessed 18-22 Jan 2021

Foundation for Young Australians (FYA). (2018). The New Work Order Report Series. Retrieved from https://www.fya.org.au/report/new-work-order-summary/. Accessed 18-22 Jan 2021

Foundation for Young Australians. (2020). The New Work Standard. Retrieved from https://www.fya.org. au/wp-content/uploads/2020/07/FYA-New-Work-Standard-2020.pdf. Accessed 18-22 Jan 2021

Furbish, D., \& Reid, L. (2013). Best practices in career education and development in New Zealand secondary schools. Australian Journal of Career Development, 22(1), 14-20. https://doi.org/10.1177/ 1038416213480952 
Glaser, B. \& Strauss, A. (1967). The discovery of grounded theory: Strategies for qualitative research. Chicago: Aldine de Gruyter.

Gore, J., Holmes, K., Smith, M., Fray, L., McElduff, P., Weaver, N., \& Wallington, C. (2017). Unpacking the career aspirations of Australian school students: Towards an evidence base for university equity initiatives in schools. Higher Education Research and Development, 36(7), 1383-1400. https://doi.org/10.1080/07294360.2017.1325847

Gore, J., Holmes, K., Smith, M., Lyell, A., Ellis, H., \& Fray, L. (2015). Choosing University: The Impact of Schools and Schooling. Retrieved from https://www.ncsehe.edu.au/publications/choos ing-university-the-impact-of-schools-and-schooling/. Accessed 18-22 Jan 2021

Greenbank, P. (2009). Re-evaluating the role of social capital in the career decision-making behaviour of working-class students. Research in Post-Compulsory Education, 14(2), 157-170. https://doi. org/10.1080/13596740902921463

Greenbank, P. (2011). 'I'd rather talk to someone I know than somebody who knows'-The role of networks in undergraduate career decision-making. Research in Post-Compulsory Education, 16(1), 31-45. https://doi.org/10.1080/13596748.2011.549726

Hooley, T., \& Dodd, V. (2015). The Economic Benefits of Career Guidance. Retrieved from https:// cica.org.au/wp-content/uploads/Careers-England-Research-Paper-The-Economic-Benefits-ofCareer-Guidance-July-2015.pdf. Accessed 18-22 Jan 2021

International Centre for Career Development and Public Policy (ICCDPP). (2019). Investing in career guidance: joint statement of OECD, ILO, UNESCO, The European Commission and its agencies ETF and CEDEFOP. Retrieved from https://www.iccdpp.org/investing-in-career-guidancejoint-statement-of-oecd-ilo-unesco-the-european-commission-and-its-agencies-etf-and-cedefopdecember-2019/. Accessed 18-22 Jan 2021

Irving, B. (2009). Locating social justice in career education: What can a small-scale study from New Zealand Tell Us? Australian Journal of Career Development, 18(2), 13-23.

Kaiserfeld, T. (2013). Creativity in invention, theories. In E. Carayannis (Ed.), Encyclopedia of creativity, invention, innovation, and entrepreneurship (pp. 409-420). Springer.

Lamb, S., Jackson, J., Walstab, A., \& Huo, S. (2015). Educational opportunity in Australia 2015: who succeeds and who misses out. Retrieved from http://www.mitchellinstitute.org.au/wp-conte nt/uploads/2015/11/Educational-opportunity-in-Australia-2015-Who-succeeds-and-who-missesout-19Nov15.pdf. Accessed 18-22 Jan 2021

Li, I., \& Carroll, D. (2017). Factors influencing university student satisfaction, dropout and academic performance. Retrieved from https://www.ncsehe.edu.au/wp-content/uploads/2017/03/03LiU WA_Formatted_FINAL.pdf. Accessed 18-22 Jan 2021

Mann, A., Denis, V., Schleicher, A., Ekhtiari, H., Forsyth, T., Liu, E., \& Chambers, N. (2020). Dream Jobs? Teenagers' career aspirations and the future of work. Organization of economic cooperation and development.

McLachlan, R., Gilfilan, G., \& Gordon, J. (2013). Deep and Persistent Disadvantage in Australia. Retrieved from https://www.pc.gov.au/research/supporting/deep-persistent-disadvantage/deeppersistent-disadvantage.pdf. Accessed 18-22 Jan 2021

Ministerial Council on Education, E., Training and Youth Affairs (MCEECDYA). (2010). Australian Blueprint for Career Development. Retrieved from https://docs.education.gov.au/system/files/ doc/other/australian_blueprint_for_career_development.pdf. Accessed 18-22 Jan 2021

Moote, J., \& Archer, L. (2018). Failing to deliver? Exploring the current status of career education provision in England. Research Papers in Education, 33(2), 187-215. https://doi.org/10.1080/ 02671522.2016.1271005

NSW Government. (2019). Careers and transitions advisers. Retrieved from https://education.nsw. gov.au/teaching-and-learning/curriculum/career-learning-and-vet/career-learning/high-schoolcareer-learning. Accessed 18-22 Jan 2021

OECD. (2016). Enhancing employability. Retrieved from https://www.oecd.org/g20/topics/emplo yment-and-social-policy/Enhancing-Employability-G20-Report-2016.pdf. Accessed 18-22 Jan 2021

OECD. (2019). Career guidance policy review home page. Retrieved from https://www.oecd.org/ education/innovation-education/careerguidancepolicyreviewhomepage.htm. Accessed 18-22 Jan 2021

OECD, ILO, UNESCO, \& The European Commission. (2019). Investing in career guidance. Retrieved from https://www.cedefop.europa.eu/files/2227_en.pdf?utm_source=activetrail\&utm_medium= email\&utm_campaign=jmc@iccdpp.org. Accessed 18-22 Jan 2021 
Office for Students. (2019). National Collaborative Outreach Programme: Phase two guidance. Retrieved from https://www.officeforstudents.org.uk/media/25f4ba6f-012b-4a31-afad-931eb97c3f61/ofs2019_ 25.pdf. Accessed 18-22 Jan 2021

Parliament of Victoria. (2018). Inquiry into career advice activities in Victorian schools. Retrieved from https://www.parliament.vic.gov.au/images/stories/committees/eejsc/Career_Advice_Activities/ EEJSC_58-04_Text_WEB.pdf. Accessed 18-22 Jan 2021

Patton, W. (2019). Career development as a partner in nation building Australia: Origins, history, and foundations for the future. Sense/Brill.

Powell, J., \& Solga, H. (2010). Analyzing the nexus of higher education and vocational training in Europe: A comparative-institutional framework. Studies in Higher Education, 35(6), 705-721.

Raciti, M. (2019). Career construction, future work and the perceived risks of going to university for young people from low SES backgrounds: Research Fellowship Final Report. Retrieved from https:// ncsehe.edu.au/wp-content/uploads/2019/07/Report_MariaRaciti_FINAL.pdf. Accessed 18-22 Jan 2021

Ranasinghe, R., Chew, E., Knight, G., \& Siekmann, G. (2019). School-to-work pathways. Retrieved from https://www.ncver.edu.au/research-and-statistics/publications/all-publications/school-to-work-pathw ays. Accessed 18-22 Jan 2021

Skillsroad. (2018). Skillsroad 2018 Youth Census Report. Retrieved from https://cica.org.au/wp-content/ uploads/Skillsroad-2018-Youth-Census-Report.pdf. Accessed 18-22 Jan 2021

Smith, L. (2011). Experiential 'hot' knowledge and its influence on low-SES students' capacities to aspire to higher education. Critical Studies in Education, 52(2), 165-177. https://doi.org/10.1080/17508 487.2011.572829

Torii, K. (2018). Connecting the worlds of learning and work. Retrieved from https://www.vu.edu.au/ sites/default/files/connecting-the-worlds-of-learning-and-work-mitchell-institute.pdf. Accessed 18-22 Jan 2021

Vernon, L., \& Drane, C. (2021). Influencers: the importance of discussions with parents, teachers and friends to support vocational and university pathways. International Journal of Training ResearchOnline First. https://doi.org/10.1080/14480220.2020.1864442

Whiston, S., Li, Y., Mitts, N., \& Wright, L. (2017). Effectiveness of career choice interventions: A metaanalytic replication and extension. Journal of Vocational Behavior, 100, 175-184. https://doi.org/ 10.1016/j.jvb.2017.03.010

Yates, A., \& Bruce, M. (2017). The future of career education in New Zealand secondary schools: A review of the literature. Australian Journal of Career Development, 26(2), 62-70. https://doi.org/10. $1177 / 1038416217700421$

Youth Action. (2017). The missing link in school to work transitions: Youth action policy paper. Retrieved from https://cica.org.au/wp-content/uploads/2017-07-18__Career_paper_formatted_FINAL_ RS.pdf. Accessed 18-22 Jan 2021

Publisher's Note Springer Nature remains neutral with regard to jurisdictional claims in published maps and institutional affiliations.

Olivia Groves is a Postdoctoral Research Fellow and experienced educator, having taught diverse learners across Australia and Asia in primary, language education and tertiary settings. Olivia's research interests lie in understanding the conditions under which learning takes place in order to maximise the potential for learning and success of all students. Her current research activity examines how student equity can be achieved in the higher-education sector and beyond-including research into best-practice career education, particularly for those with disability; supporting student success in higher education in the time of COVID; and understanding and ameliorating inequities in graduate outcomes.

Kylie Austin has 12 years' experience working in the higher-education sector leading the strategic planning of student equity initiatives. Over this period, Kylie has led the implementation of Outreach, Transition and Co-Curricular programs that aim to increase the participation of students from identified equity backgrounds in higher education. Kylie has a significant research interest in how partnerships can increase outcomes for students from equity students across the student lifecycle. Kylie has led and been involved in national research projects that have focused on widening participation to higher education and 
is the current President of Equity Practitioners in Higher Education Australasia (EPHEA).

Sarah O'Shea is the Director of the National Centre for Student Equity in Higher Education (NCSEHE) which is hosted by Curtin University. Sarah has spent over twenty-five years working to effect change within the higher-education (HE) sector through research that focuses on the access and participation of students from identified equity groups. Her institutional and nationally funded research studies advance understanding of how under-represented student cohorts enact success within university, navigate transition into this environment, manage competing identities and negotiate aspirations for self and others. Sarah has published extensively in the field and has been awarded over \$AUD3 million in grant funding since 2009, she is also an Australian Learning and Teaching Fellow (ALTF), a Principal Fellow of the Higher Education Academy (PFHEA), and a Churchill Fellow (CF).

Jodi Lamanna works within the tertiary sector as a sessional academic in the field of education, and as a research assistant within the School of Education and previously in the Faculty of Science, Medicine and Health. Jodi's research skills support high quality, impactful qualitative and quantitative research which aims to increase the body of knowledge and influence policy and practice. Recent work in the equity sector aligns with Jodi's passion for equity in education. Jodi's current work in career development learning is complimentary to her doctoral research which focuses on the reversal and prevention of underachievement in gifted students, viewed through the lens of lived experience. The research utilises a qualitative approach and has the potential to bring about changes in the classroom to support the learning needs of gifted, underachieving students. 